\title{
Optimization of Invertase Production Using Saccharomyces Cerevisiae MK Under Varying Cultural Conditions
}

\author{
T. Shankar*, P. Thangamathi, R. Rama, T. Sivakumar \\ Department of Microbiology, Ayya Nadar Janaki Ammal College, Sivakasi-626124,Tamil Nadu, India \\ *Corresponding Author: ewcellulase@gmail.com
}

Copyright (C) 2013 Horizon Research Publishing All rights reserved.

\begin{abstract}
A Saccharomyces cerevisiae MK was isolated from toddy sample. The effect of different production parameters such as $\mathrm{pH}$, temperature, incubation time, carbon source, nitrogen source (organic and inorganic), inoculum concentrations, sucrose concentrations, metal ions, surfactants, amino acids, buffers, agricultural residues and agricultural residue concentration on invertase production by the isolated Saccharomyces cerevisiae MK strain were studied. The enzyme production was assayed in submerged fermentation $(\mathrm{SmF})$. Maximum invertase activity was found at $\mathrm{pH} 6,30^{\circ} \mathrm{C}, 48$ hours, sucrose, yeast extract (organic nitrogen), ammonium chloride (inorganic nitrogen), $2 \%$ inoculum concentration, $2 \%$ sucrose concentration, calcium chloride, poly ethylene glycol, methionine, citrate buffer, orange peel-4\%. A higher titre of invertase enzyme activity $(0.48 \pm 0.011 \mathrm{IU} / \mathrm{ml})$ was obtained in the optimized production medium.
\end{abstract}

Keywords Invertase, Optimization, Saccharomyces Cerevisiae $\mathrm{MK}, \mathrm{SmF}$

\section{Introduction}

Invertase catalyzes the hydrolysis of sucrose to glucose and fructose. The resulting mixture of fructose and glucose is called inverted sugar syrup which is sweeter than sucrose [1]. Invertase is one of the most extensively recycled enzymes in food engineering, especially in the preparation of jams and candies. The enzyme is a glycoprotein, with some residues of mannose being the major component of the carbohydrate moiety. Invertase is mainly used in the food industry, where fructose is preferred over sucrose because it is sweeter and does not crystallize easily [2].

Many organisms produce invertase such as Neurospora crassa, Candida utilis, Fusarium oxysporium, Phytophthora meganosperma, Aspergillus niger, Saccharomyces cerevisiae, Schizosaccharomyces pombe and
Schwanniomyces occidentalis [3]. Saccharomyces cerevisiae is the organism of choice for invertase construction because of its distinguishing high sucrose fermentation ability. Sucrose is considered to be the best sole carbon source for invertase production as the availability of glucose for yeast is dependent on sucrose hydrolysis by invertase. Therefore, sucrose concentration markedly influences invertase biosynthesis [4].

Invertases may be found in different isoforms according to their $\mathrm{pH}$ optimum. However, the specific function of these isoforms is not well-known, but they appear to control the entry of sucrose into altered exploitation pathways [5]. The acidic form has cell-wall or vacuolar localization and it is evolutionary related to yeast and bacterial invertases, differing of neutral and alkaline isoforms that are found on the cytosol. In yeast, the gene Suc 2 encodes two different invertases, a glycosylated form located in periplasmic space and a non-glycosylated form situated in the cytosol [6].

Refinement situations are essential in successful production of an enzyme and optimization of parameters such $\mathrm{pH}$, temperature and media composition is important in developing the optimum fermentation conditions [7]. The aim of this work was to heighten the cultural condition for the making of invertase enzyme by a $S$. cerevisiae MK isolated from toddy taster.

\section{Materials and Methods}

\subsection{Effect of $\mathrm{pH}$ on invertase production}

The effect of optimum $\mathrm{pH}$ for invertase production by Saccharomyces cerevisiae MK was determined by culturing the yeast in the production media with different $\mathrm{pH}$. The experiment was carried out individually at various $\mathrm{pH}$ such as $2,3,4,5,6,7,8,9$ and 10 . The enzyme assay was carried out after 48 hours of incubation at $30^{\circ} \mathrm{C}[8]$.

\subsection{Effect of Temperature on Invertase Production}


Temperature plays an important role for the production of the invertase by Saccharomyces cerevisiae MK. The effect of temperature on invertase production was studied by incubating the culture media at various temperatures such as $10,20,30,40,50$ and $60^{\circ} \mathrm{C}[9]$.

\subsection{Effect of Incubation Time on Invertase Production}

The effect of incubation time on invertase production by Saccharomyces cerevisiae MK was determined by culturing the yeast in the production media. The experiment was carried out individually at various incubation times. They were 24, 48, 72 and 96 hours [10].

\subsection{Effect of Carbon Sources on Invertase Production}

To identify suitable carbon source for the invertase production by Saccharomyces cerevisiae MK, the following carbon sources were tested. The production medium containing sucrose, act as a carbon source. This sucrose was replaced by trehalose, maltose, galactose, mannose, fructose, glucose, raffinose, arabinose, lactose, xylose, starch, carboxy methyl cellulose and sucrose. These carbon sources were tested individually at the concentration of $1 \%$ with dry substrate in the optimized production medium. The enzyme assay was carried out after 48 hours of incubation at $30^{\circ} \mathrm{C}$ [11].

\subsection{Effect of Organic Nitrogen Sources on Invertase Production}

The invertase production by Saccharomyces cerevisiae MK was optimized by supplementing different organic nitrogen sources. For this, six different organic nitrogen sources were tested individually at the concentration of $0.5 \%$ with dry substrate in the optimized carbon sources in production medium. The organic nitrogen sources used were yeast extract, glycine, peptone, gelatin, urea and casein. The organic nitrogen source that results maximum invertase production was then used for further study [12].

\subsection{Effect of Inorganic Nitrogen Sources on Invertase Production}

The invertase production by Saccharomyces cerevisiae MK was also optimized by supplementing different inorganic nitrogen sources. The different inorganic nitrogen sources used for the invertase production were ammonium nitrate, ammonium chloride, ammonium molybdate, potassium nitrate and sodium nitrate. They were tested individually at the concentration of $0.5 \%$ in production medium. The inorganic nitrogen source that results maximum invertase production was then used for further study [13].

\subsection{Effect of Different Concentration of Inoculum Level on Invertase Production}

Different concentration of inoculum level such as $0.5,1$, $1.5,2,2.5,3$ and $3.5 \%$ were tested for their ability to induce invertase production in the production medium [14].

\subsection{Effect of Various Concentration of Sucrose Level on Invertase Production}

Different concentration of sucrose level such as $0.5,1,1.5$, $2,2.5,3$ and $3.5 \%$ were tested for their ability to induce invertase production in the production medium [15].

\subsection{Effect of Metal Ions on Invertase Production}

In the present study to enhance invertase production ferrous sulphate, zinc sulphate, magnesium chloride, cobaltous chloride, manganese sulphate, sodium chloride and calcium chloride were tested as the source of metal ions. In this study they were incorporated individually into the production medium at the concentration of $0.02 \%$. The effect was determined after 48 hours of incubation [16].

\subsection{Effect of Surfactants on Invertase Production}

To identify the surfactants facilitating invertase production, five different surfactants were used for experimentation. They were Tween-20, Tween-80, SDS (Sodium Dodecyl Sulphate), Triton X-100 and PEG (Poly Ethylene Glycol). The selected surfactants were tested individually at the concentration of $0.2 \%$ in the optimized production medium [17].

\subsection{Effect of Amino Acids on Invertase Production}

In the present study to enhance invertase production different amino acids at the concentration of $0.2 \%$ were tested. The different amino acids sources used for the invertase production were asparginine, lysine, histidine, glutamicacid, arginine, proline, glutamine, leucine, alanine, methionine, serine, phenylalanine, aspartic acid, cysteine, tyrosine, tryptophan, isoleucine, and 1-lysine. They were introduced into the production medium individually to determine the effect of amino acids on the Invertase production [18]

\subsection{Effect of Buffers on Invertase Production}

In the present study to enhance invertase production different buffers at pH-6 were tested. The different buffers used for the invertase production were sodium phosphate buffer, phosphate buffer, citrate buffer and potassium phosphate buffer. In this study optimized sources were incorporated into the production medium containing $0.1 \mathrm{M}$ buffer at $\mathrm{pH}$ 6. The effect was determined after 48 hours of incubation [19].

\subsection{Effect of Agricultural Residues on Invertase Production}


The invertase production by Saccharomyces cerevisiae MK was optimized by supplementing different agricultural residues. For this, seven different agricultural residues were tested individually at the concentration of $2 \%$ with dry powdered substrate in the optimized production medium. The different agricultural residues used for the invertase production were pomegranate peel, sappota peel, pineapple peel, orange peel, lemon peel, grape peel and sugarcane baggasse [20].

\subsection{Effect of Different Concentration of Agricultural Residue on Invertase Production}

Different concentration of agricultural residue (orange peel) such as $1,2,3,4,5,6,7,8,9$ and $10 \%$ were tested for their ability to induce invertase production by Saccharomyces cerevisiae MK in the production medium [21].

\subsection{Invertase Production Media in Solid State Fermentation (SSF)}

The $(250 \mathrm{ml})$ Erlenmeyer flasks containing $40 \mathrm{~g}$ of agricultural substrate (orange peel) and $20 \mathrm{ml}$ of production medium containing $(\mathrm{g} / \mathrm{l})$; sucrose $-10.0 \mathrm{~g}$, yeast extract $-5.0 \mathrm{~g}$, ammonium chloride - $0.5 \mathrm{~g}$, calcium chloride - $0.2 \mathrm{~g}$, polyethyleneglycol $-2.0 \mathrm{~g}$, methionine $-2.0 \mathrm{~g}, 0.1 \mathrm{M}$ citrate buffer at pH-6 composition: citric acid - 9.5g and sodium citrate $-40.5 \mathrm{~g}$. The yeast Saccharomyces cerevisiae MK was inoculated and incubated for 48 hours. At the end of the fermentation $50 \mathrm{ml}$ distilled water was added to the fermented substrate and kept in shaker for 1 hour. Then it was centrifuged at $10,000 \mathrm{rpm}$ for 5 minutes and the supernatant was used for further analytical work.

\subsection{Invertase Production Media in Submerged Fermentation (SmF)}

The $(250 \mathrm{ml})$ Erlenmeyer flasks containing $40 \mathrm{~g}$ of agricultural substrate (orange peel) and $50 \mathrm{ml}$ of production medium containing $(\mathrm{g} / \mathrm{l})$; sucrose $-10.0 \mathrm{gm} / \mathrm{L}$, yeast extract $5.0 \mathrm{gm} / \mathrm{L}$, ammonium chloride $-0.5 \mathrm{gm} / \mathrm{L}$, calcium chloride $0.2 \mathrm{gm} / \mathrm{L}$, polyethyleneglycol $-2.0 \mathrm{gm} / \mathrm{L}$, methionine $2.0 \mathrm{gm} / \mathrm{L}, 0.1 \mathrm{M}$ citrate buffer at $\mathrm{pH}-6$ composition: citric acid - $9.5 \mathrm{gm} / \mathrm{L}$ and sodium citrate - $40.5 \mathrm{gm} / \mathrm{L}$. The yeast Saccharomyces cerevisiae MK was inoculated individually and incubated for 48 hours.

\section{Result}

\subsection{Effect of pH on invertase production}

The effect of different $\mathrm{pH}$ on invertase production after 48 hours of incubation period at $30^{\circ} \mathrm{C}$ showed maximum amount of invertase production at $\mathrm{pH} 6.0(0.35 \pm 0.005)$. The minimum Invertase production was recorded at $\mathrm{pH} 8.0(0.11$

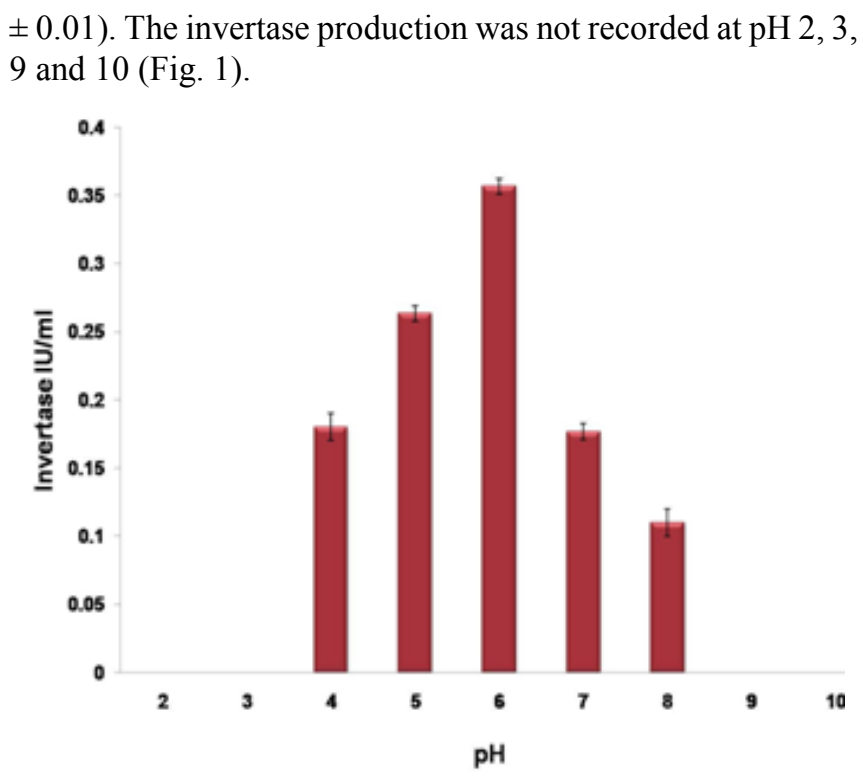

Figure 1. Effect of $\mathrm{pH}$ on Invertase production by Saccharomyces cerevisiae $\mathrm{MK}$

\subsection{Effect of Temperature on Invertase Production}

Among the various temperatures tested, the maximum invertase production was obtained at $30^{\circ} \mathrm{C}$ temperature $(0.34$ $\pm 0.005 \mathrm{IU} / \mathrm{ml})$. On the other hand, the minimum amount of invertase production was observed at temperature $10^{\circ} \mathrm{C}(0.01$ $\pm 0.011 \mathrm{IU} / \mathrm{ml}$ ) (Fig. 2).

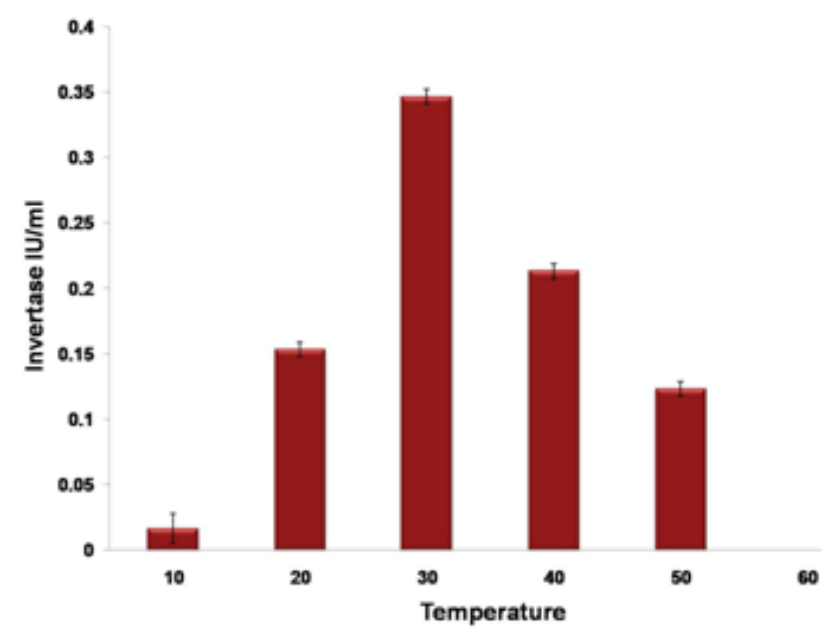

Figure 2. Effect of temperature on invertase production by Saccharomyces cerevisiae MK

\subsection{Effect of Various Incubation Intervals on Invertase Production}

The effect of different kinds of incubation time was tested on invertase production. The maximum amount of invertase production was observed in 48 hours incubation time $(0.36 \pm$ $0.015 \mathrm{IU} / \mathrm{ml}$ ). The minimum amount of invertase production was obtained in 96 hours of incubation time $(0.08 \pm 0.004 \mathrm{IU}$ 
IU/ml) (Fig. 3).

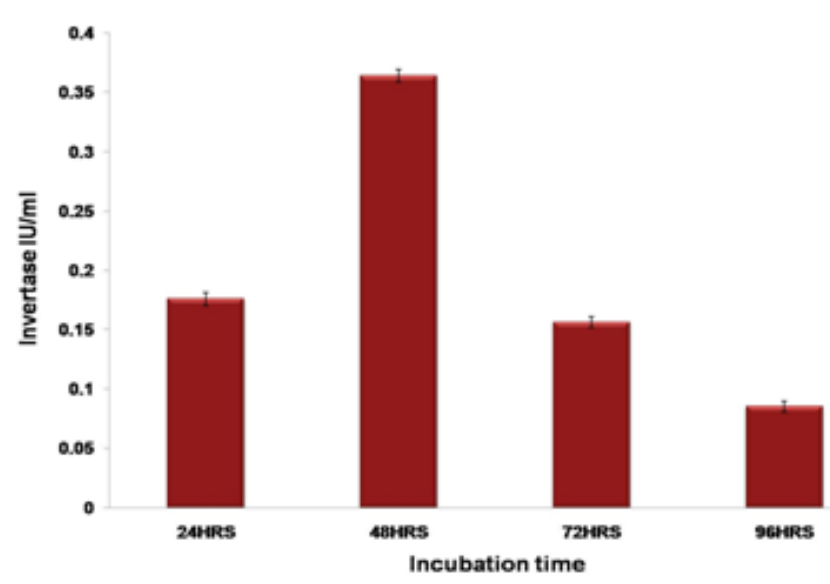

Figure 3. Effect of incubation time on invertase production by Saccharomyces cerevisiae MK

\subsection{Effect of Carbon Sources on Invertase Production}

The effect of carbon sources on invertase production by Saccharomyces cerevisiae MK after 48 hours of incubation period at $30^{\circ} \mathrm{C}$ is given in (Fig. 4). Here the maximum invertase production was recorded in sucrose $(0.36 \pm 0.005$ $\mathrm{IU} / \mathrm{ml}$ ) supplemented medium. The minimum invertase production was recorded in lactose $(0.01 \pm 0.005 \mathrm{IU} / \mathrm{ml})$ added medium. The invertase production was not recorded at xylose and trehalose.

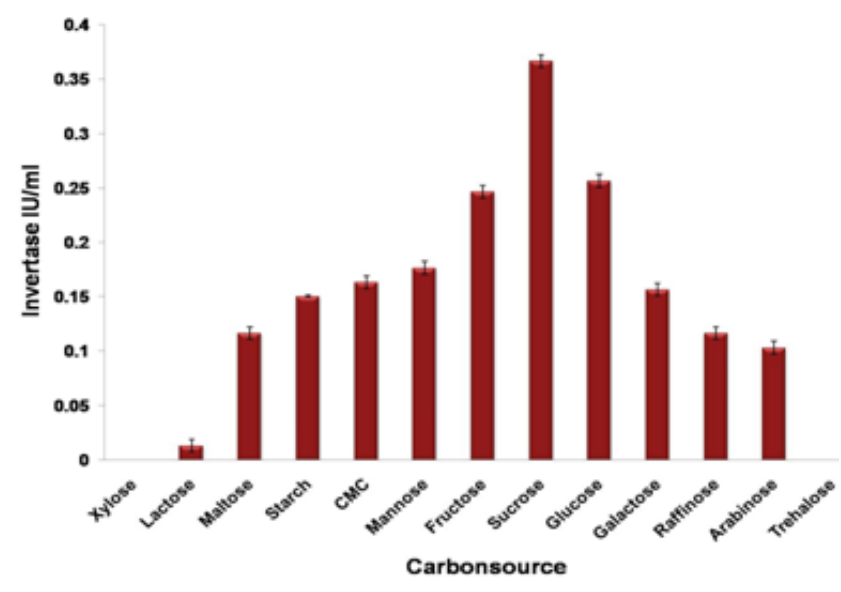

Figure 4. Effect of carbon sources on invertase production by Saccharomyces cerevisiae MK

\subsection{Effect of Organic Nitrogen Sources on Invertase Production}

The effect of different kinds of organic nitrogen sources on invertase production after 48 hours of incubation period at $30^{\circ} \mathrm{C}$ showed maximum amount of enzyme production in yeast extract $(0.25 \pm 0.005 \mathrm{IU} / \mathrm{ml})$ supplemented medium and minimum amount of invertase production in urea $(0.08 \pm 0.005 \mathrm{IU} / \mathrm{ml})$ supplemented medium (Fig. 5).

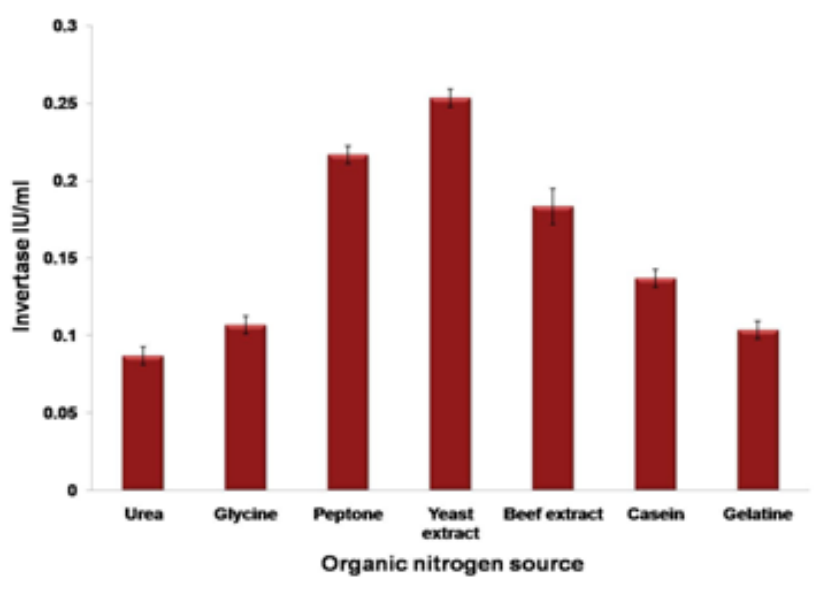

Figure. 5: Effect of organic nitrogen sources on invertase production bySaccharomyces cerevisiae MK

\subsection{Effect of Inorganic Nitrogen Sources on Invertase Production}

The effect of different kinds of inorganic nitrogen sources on invertase production after 48 hours of incubation period at $30^{\circ} \mathrm{C}$ showed maximum amount of enzyme production in ammonium chloride $(0.28 \pm 0.11 \mathrm{IU} / \mathrm{ml})$ supplemented medium and minimum amount of invertase production in potassium nitrate $(0.15 \pm 0.005 \mathrm{IU} / \mathrm{ml})$ supplemented medium (Fig. 6).

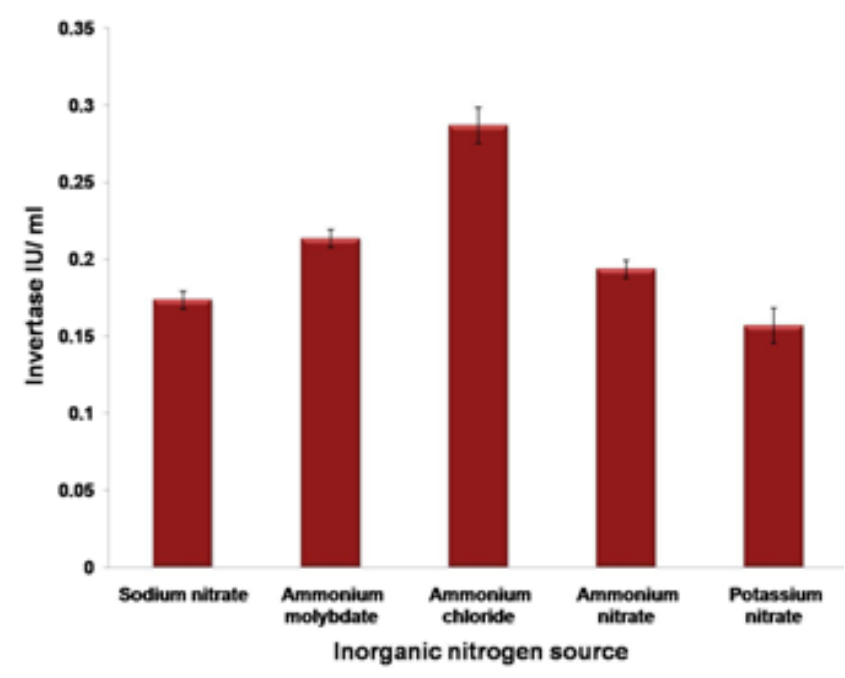

Figure 6. Effect of inorganic nitrogen sources on invertase production by Saccharomyces cerevisiae MK

\subsection{Effect of Different Concentration of Inoculum on Invertase Production}

The initial inoculum level in the invertase media is a critical factor in fermentation process. The maximum invertase activity was registered at the $2 \%(0.37 \pm 0.005$ $\mathrm{IU} / \mathrm{ml}$ ) of inoculum level. On the other hand, the minimum amount of invertase production was observed at $3.5 \%$ of $(0.29 \pm 0.015 \mathrm{IU} / \mathrm{ml})$ inoculums level (Fig. 7). 


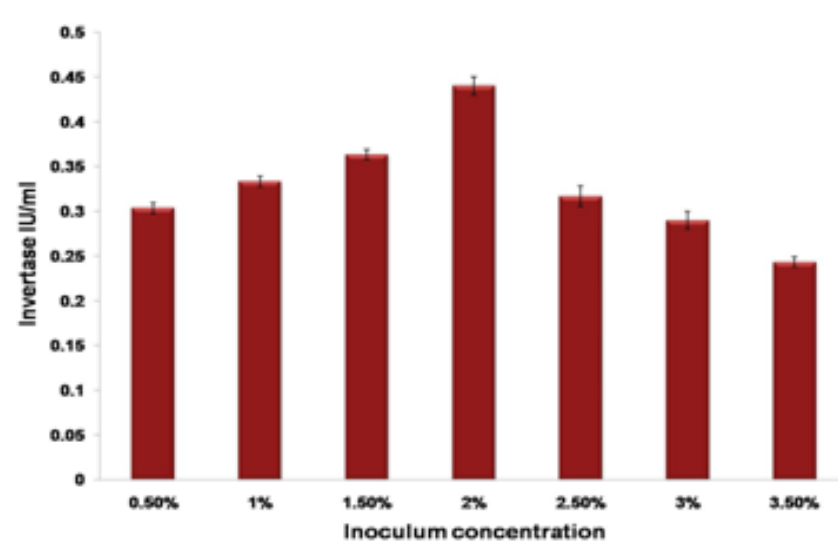

Figure 7. Effect of different concentration of inoculum level on invertase production by Saccharomyces cerevisiae MK

\subsection{Effect of Different Concentration of Sucrose on Invertase Production:}

The effect of different concentration of sucrose on invertase production after 48 hours of incubation period at $30^{\circ} \mathrm{C}$ showed maximum amount of enzyme production in $2 \%$ $(0.4 \pm 0.005 \mathrm{IU} / \mathrm{ml})$ supplemented medium and minimum amount of invertase production in $3.5 \%(0.03 \pm 0.005 \mathrm{IU} / \mathrm{ml})$ supplemented medium (Fig. 8).

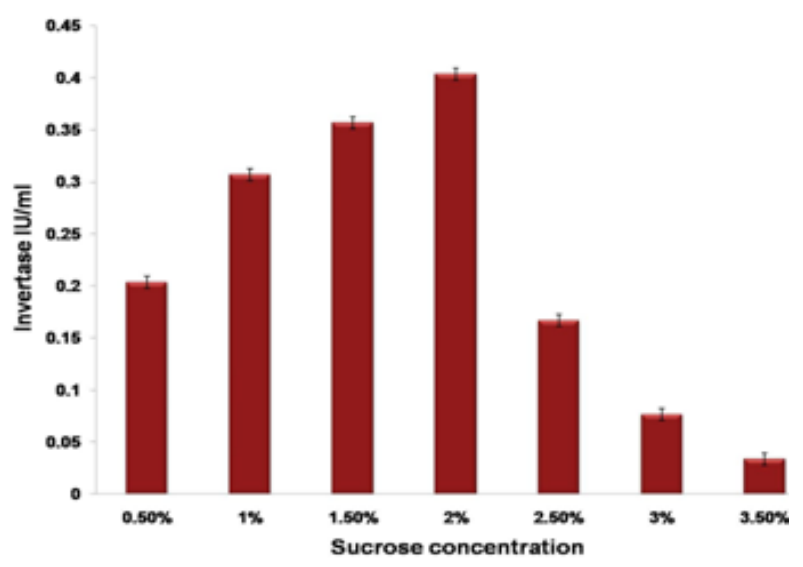

Figure 8. Effect of various concentration of sucrose level on invertase production by Saccharomyces cerevisiae MK

\subsection{Effect of Metal Ions on Invertase Production}

Among the tested metal ions, the maximum amount of enzyme production was recorded in calcium chloride $(0.128$ $\pm 0.001 \mathrm{IU} / \mathrm{ml}$ ) added medium. Followed by this, magnesium sulphate $(0.120 \pm 0.005 \mathrm{IU} / \mathrm{ml})$ was the second best metal ions on invertase production, whereas the minimum amount of invertase production was observed in manganese sulphate $(0.07 \pm 0.005 \mathrm{IU} / \mathrm{ml})$ supplemented medium (Fig. 9).

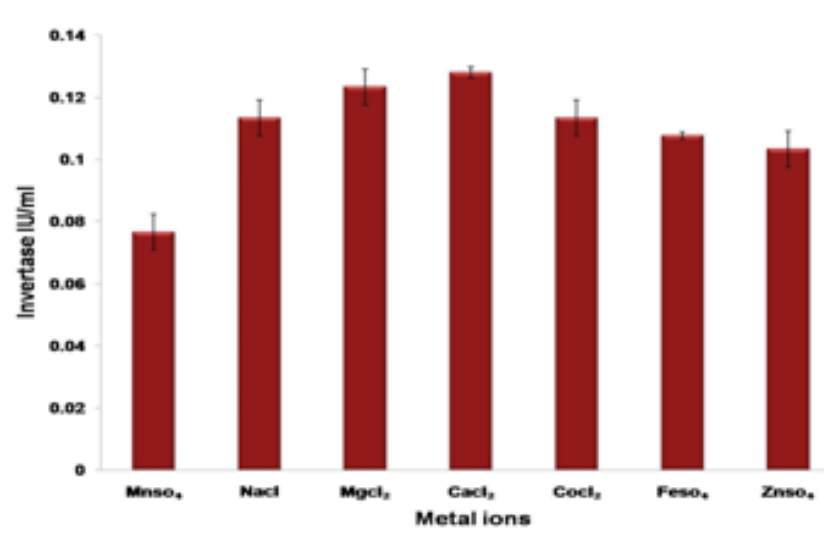

Figure 9. Effect of metal ions on invertase production by Saccharomyces cerevisiae MK

\subsection{Effect of Surfactants on Invertase Production}

The effect of different kinds of surfactants was tested on invertase production after 48 hours of incubation period at $30^{\circ} \mathrm{C}$. Among the tested surfactants, the maximum amount of enzyme production was recorded in Poly ethylene glycol $(0.21 \pm 0.005 \mathrm{IU} / \mathrm{ml})$ added medium. The minimum amount of invertase enzyme production was recorded in Tween-20 $(0.09 \pm 0.005 \mathrm{IU} / \mathrm{ml})$ supplemented medium (Fig. 10).

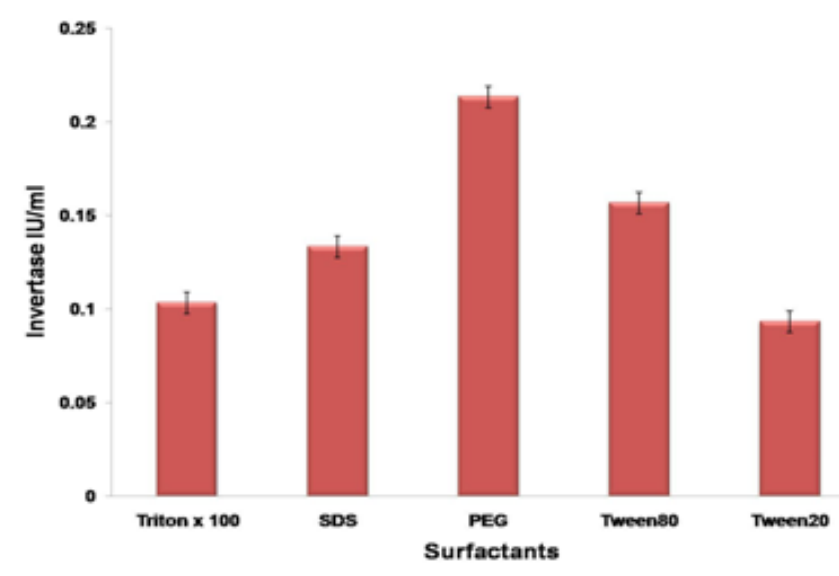

Figure 10. Effect of surfactants on invertase production by Saccharomyces cerevisiae MK

\subsection{Effect of Amino Acids on Invertase Production}

The effect of different kinds of aminoacids was tested on invertase production after 48 hours of incubation period at $30^{\circ} \mathrm{C}$. Among the tested aminoacids, the maximum amount of enzyme production was recorded in methionine $(0.33 \pm$ $0.005 \mathrm{IU} / \mathrm{ml}$ ) added medium. The minimum amount of invertase enzyme production was recorded in L-lysine $(0.06$ $\pm 0.005 \mathrm{IU} / \mathrm{ml}$ ) supplemented medium (Fig. 11). 


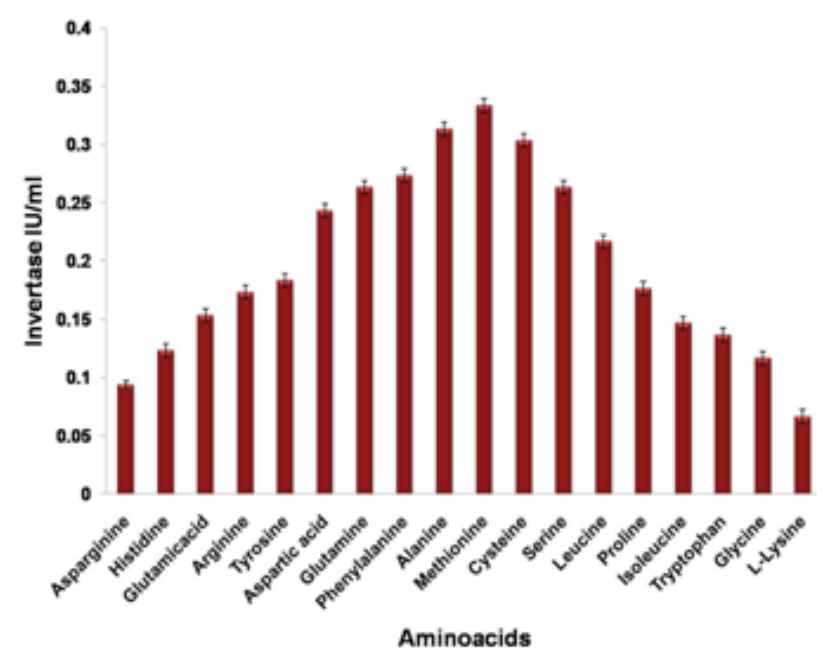

Figure 11. Effect of amino acids on invertase production by Saccharomyces cerevisiae MK

\subsection{Effect of Buffer on Invertase Production}

The effect of different kinds of buffers was tested on invertase production after 48 hours of incubation period at $30^{\circ} \mathrm{C}$. Here the maximum invertase production was recorded in citrate buffer $(0.23 \pm 0.005 \mathrm{IU} / \mathrm{ml})$ supplemented medium. The minimum invertase production was recorded in sodium phosphate buffer $(0.14 \pm 0.005 \mathrm{IU} / \mathrm{ml})$ added medium (Fig. 12).

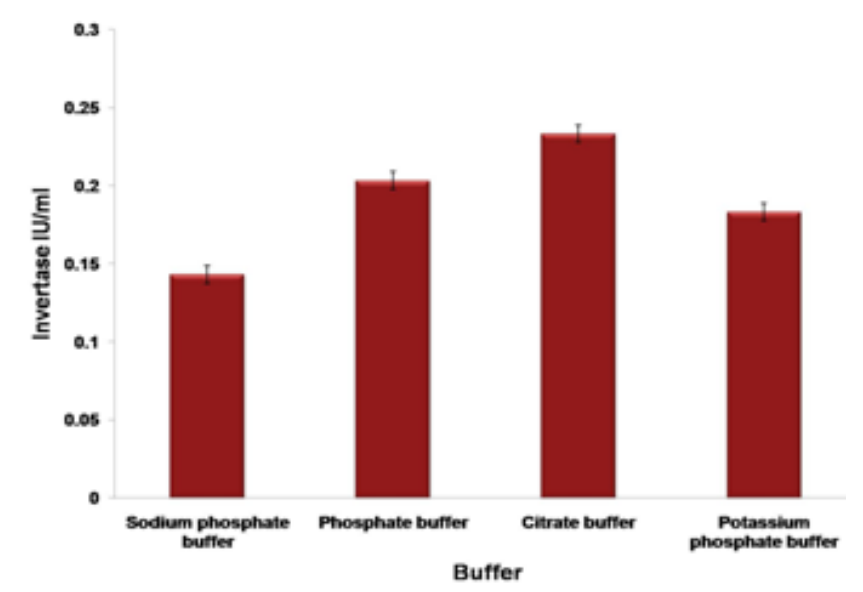

Figure 12. Effect of buffers on invertase production by Saccharomyces cerevisiae MK

\subsection{Effect of Agricultural Residue on Invertase Production}

Different agricultural by products such as pomegranate peel, sappota peel, pineapple peel, orange peel, lemon peel, grape peel and sugarcane baggasse were tested for the production of invertase enzyme. The maximum invertase production was recorded in orange peel $(0.36 \pm 0.011)$ supplemented medium. The minimum invertase production was recorded sin sugarcane baggasse $(0.13 \pm 0.011 \mathrm{IU} / \mathrm{ml})$ added medium (Fig. 13)

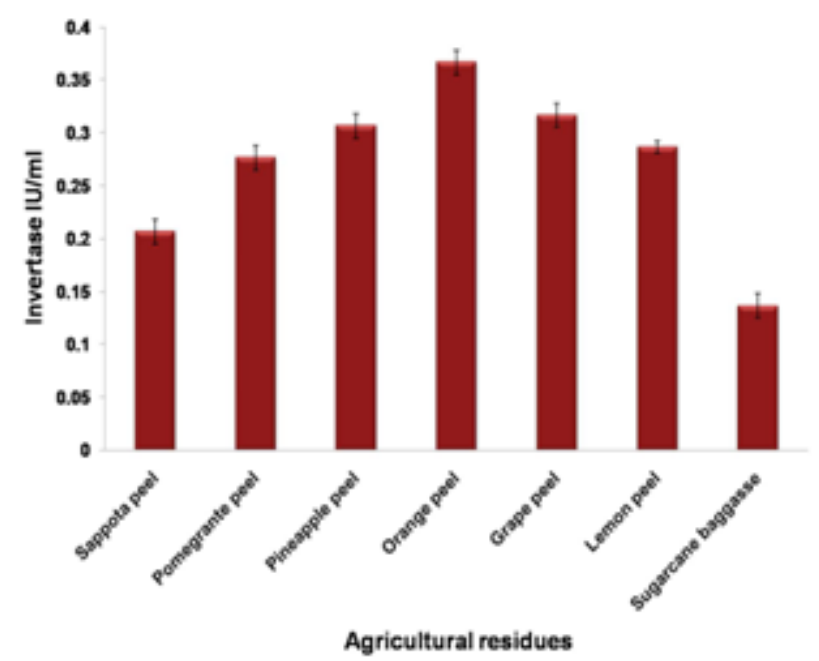

Figure 13. Effect of agricultural residues on invertase production by Saccharomyces cerevisiae MK

\subsection{Effect of Different Concentration of Agricultural Residue on Invertase Production}

The effect of different concentration of agricultural residue (orange peel) on invertase production after 48 hours of incubation period at $30^{\circ} \mathrm{C}$ showed maximum amount of enzyme production in $4 \% \quad(0.48 \pm 0.011 \mathrm{IU} / \mathrm{ml})$ supplemented medium and minimum amount of invertase production in $10 \%(0.08 \pm 0.005 \mathrm{IU} / \mathrm{ml})$ supplemented medium (Fig. 14).

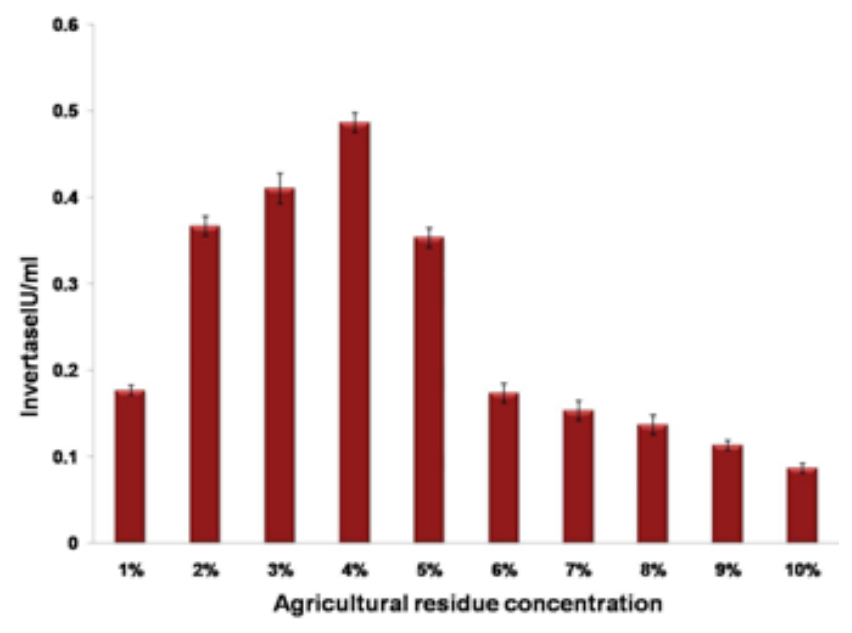

Figure 14. Effect of different concentration of agricultural residue (orange peel) on invertase Production by Saccharomyces cerevisiae MK

\subsection{Invertase Production in Solid State and Submerged Fermentation}

In solid state fermentation, invertase production recorded 
by Saccharomyces cerevisiae MK was $0.46 \pm 0.01 \mathrm{IU} / \mathrm{ml}$ and submerged fermentation, invertase production recorded by Saccharomyces cerevisiae MK was $0.49 \pm 0.005$ IU/ml (Fig. 15).

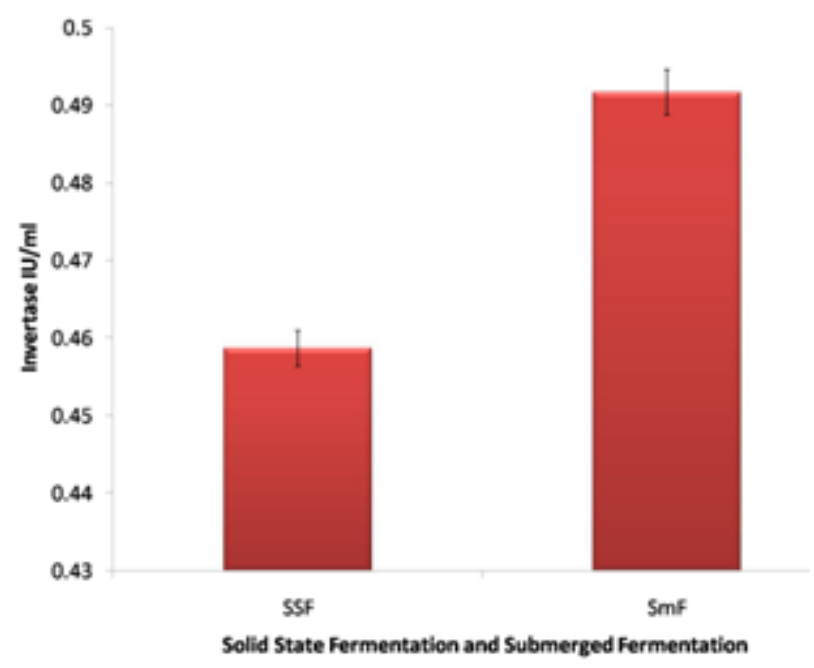

Figure 15. Effect of Solid State Fermentation and Submerged Fermentation on invertase production by Saccharomyces cerevisiae MK

\section{Discussion}

The product of initial $\mathrm{pH}$ on enzyme production by Saccharomyces cerevisiae MK was investigated in current study. Maximum amount of invertase production of $0.35 \pm$ $0.005 \mathrm{IU} / \mathrm{ml}$ was obtained at $\mathrm{pH} 6.0$ and minimum invertase production of $0.11 \pm 0.01 \mathrm{IU} / \mathrm{ml}$ was recorded in $\mathrm{pH} 8.0$ by Saccharomyces cerevisiae MK. Ul-Haq and Ali, (2005) also specified that the maximum production of invertase was obtained while early $\mathrm{pH}$ of the fermentation medium was retained at 6.0. A less enzyme production at developed $\mathrm{pH}$ was due to blocked enzyme secretion from the yeast cells $[22,23]$.

In the present examination the effect of temperature on invertase production by Saccharomyces cerevisiae MK was studied. Maximum invertase production of $0.34 \pm 0.005$ $\mathrm{IU} / \mathrm{ml}$ observed at $30^{\circ} \mathrm{C}$ and minimum invertase production of $0.01 \pm 0.011 \mathrm{IU} / \mathrm{ml}$ was recorded at $10^{\circ} \mathrm{C}$ by Saccharomyces cerevisiae MK. Similarly, the temperature $30^{\circ} \mathrm{C}$ for invertase production was also reported and optimum temperature for invertase activity was $50^{\circ} \mathrm{C}$ for Saccharomyces cerevisiae NRRLY 12623[24.25].

In the present work the invertase production was studied by varying the incubation time from $24-96$ hours for Saccharomyces cerevisiae MK. Maximum amount of invertase production of $0.36 \pm 0.015 \mathrm{IU} / \mathrm{ml}$ was recorded in 48 hours and minimum invertase production of $0.08 \pm 0.004$ $\mathrm{IU} / \mathrm{ml}$ was recorded in 96 hours incubation time by Saccharomyces cerevisiae MK. Similar results were also reported for invertase production by Saccharomyces cerevisiae culture medium incubated for 24-48 hours and stated that invertase by Aspergillus flavus was reached between the 72-92 hours of time rests. Time course study is one of the most critical factors, which governs the value of the process along with product formation. The pattern of accumulated reducing sugar after specific incubation time is characteristic to the each species. Conservation of cell feasibility throughout the fermentation process is an important factor that depends on medium composition and incubation condition $[27,28]$.

The different carbon source was investigated for invertase production by Saccharomyces cerevisiae MK. Maximum amount of invertase production of $0.36 \pm 0.005 \mathrm{IU} / \mathrm{ml}$ was recorded in sucrose and minimum invertase production of $0.01 \pm 0.005 \mathrm{IU} / \mathrm{ml}$ was recorded in lactose by Saccharomyces cerevisiae MK. The similar result was also reported by [29] that invertase production was induced by sucrose in some other fungi. The proper concentration of carbon source is important for the optimum production of invertase enzyme chemohetrotrophic organisms are dependent on chemical energy sources and employ organic compounds as the principle carbon source. The lower concentration of carbon source might insufficient for the proper growth of yeast which results in less invertase production $[30,31]$.

Clearly, the present work on the effects of different organic and inorganic nitrogen sources was studied for invertase production by Saccharomyces cerevisiae MK. Maximum amount of invertase production of $0.25 \pm 0.005$ $\mathrm{IU} / \mathrm{ml}$ was recorded in yeast extract (organic nitrogen source) and minimum invertase production of $0.08 \pm 0.005 \mathrm{IU} / \mathrm{ml}$ was recorded in urea (organic nitrogen source) by Saccharomyces cerevisiae MK. Maximum amount of invertase production of $0.28 \pm 0.11 \mathrm{IU} / \mathrm{ml}$ was recorded in ammonium chloride (inorganic nitrogen source) and minimum invertase production of $0.15 \pm 0.005 \mathrm{IU} / \mathrm{ml}$ was recorded in potassium nitrate (inorganic nitrogen source) by Saccharomyces cerevisiae MK. The similar results, yeast extract and ammonium chloride was best nitrogen source for invertase production by Bacillus macerans-EG- 6 and also stated the similar result that yeast extract was best nitrogen source for invertase from a Cladosporium cladosporioides i $\mathrm{SmF}[27,32]$ Whereas, some reported that the peptone + yeast extract was significant in invertase production by Saccharomyces cerevisiae 3090[15]. The urea + yeast extract was best for invertase production for Saccharomyces cerevisiae $[39,40]$.

In the present investigation effect of various concentration of inoculum concentration on invertase production was studied in Saccharomyces cerevisiae MK. Maximum invertase production of $0.37 \pm 0.005 \mathrm{IU} / \mathrm{ml}$ by was registered at $2 \%$ inoculum level and minimum amount of invertase production of $0.29 \pm 0.015 \mathrm{IU} / \mathrm{ml}$ was registered in $3.5 \%$ inoculum level by Saccharomyces cerevisiae MK. The inoculum size was further increased, the production of the enzyme gradually decreased due to the fact that at high 
level of inoculum size yeast grow fast by consuming the essential nutrients at the initial stages and rapid accumulation of by product into the fermentation medium observed [4]. The reason for the low production of enzyme at the inoculum size below than optimal was due to the slow growth of the organism and extended time period to utilize nutrients properly. Inoculum size larger than optimal caused overgrowth of yeast and thus, nutrient imbalance resulting in less enzyme production [33].

In the current study effect of different concentration of sucrose concentration on invertase production was studied in Saccharomyces cerevisiae MK. Maximum invertase production of $0.4 \pm 0.005 \mathrm{IU} / \mathrm{ml}$ by was registered in $2 \%$ sucrose concentration and minimum amount of invertase production of $0.03 \pm 0.005 \mathrm{IU} / \mathrm{ml}$ was registered in $3.5 \%$ sucrose concentration by Saccharomyces cerevisiae MK. Whereas other reported the higher sucrose concentration was obtained at $30 \mathrm{~g} / \mathrm{L}$ of invertase production by Saccharomyces cerevisiae. This might be due to the generation of high concentration of inverted sugar in the medium which results in glucose-induced repression of invertase [33.40]. As sucrose is carbon source in the medium, lower concentrations might limit proper growth of yeast, resulting in less yield of invertase. The sucrose had certain advantages over some other sugars because of its high degree of sweetness, relatively low degree of hygroscopicity, crystal form, solubility and facility of crystallization and readily hydrolyzed with formation of invert sugar. Above optimal concentration of sucrose, a gradual decline in enzyme activity but increase in dry cell mass was recorded. The increase in enzyme production was due to that sucrose in higher concentration in the medium hydrolyzes into glucose and fructose that may not be fully utilized due to the induced carbon catabolic repression of invertase [34, 37, and 38].

In the existent work to enhance invertase production ferrous sulphate, zinc sulphate, magnesium chloride, cobaltous chloride, manganese sulphate, sodium chloride and calcium chloride were tested as the source of metal ions by Saccharomyces cerevisiae MK. Maximum amount of invertase production of $0.128 \pm 0.001 \mathrm{IU} / \mathrm{ml}$ was recorded in calcium chloride and minimum invertase production of 0.07 $\pm 0.005 \mathrm{IU} / \mathrm{ml}$ was recorded in manganese sulphate by Saccharomyces cerevisiae MK.

In the existing investigation, effect of surfactants on invertase production by Saccharomyces cerevisiae MK was studied. Maximum amount of invertase production of $0.21 \pm$ $0.005 \mathrm{IU} / \mathrm{ml}$ was recorded in poly ethylene glycol and minimum invertase production of $0.09 \pm 0.005 \mathrm{IU} / \mathrm{ml}$ was recorded in Tween-20 by Saccharomyces cerevisiae MK.

In the present-day study, effect of amino acids on invertase production by Saccharomyces cerevisiae MK was studied. Maximum amount of invertase production of $0.33 \pm$ $0.005 \mathrm{IU} / \mathrm{ml}$ was recorded in methionine and minimum invertase production of $0.06 \pm 0.005 \mathrm{IU} / \mathrm{ml}$ was recorded in L-lysine by Saccharomyces cerevisiae MK.

In the contemporary work, various buffers were used to stabilize the $\mathrm{pH}$ on invertase production by Saccharomyces cerevisiae MK was studied. maximum amount of invertase production of $0.23 \pm 0.005 \mathrm{IU} / \mathrm{ml}$ was recorded in citrate buffer and minimum invertase production of $0.14 \pm 0.005$ $\mathrm{IU} / \mathrm{ml}$ was recorded in sodium phosphate buffer by Saccharomyces cerevisiae MK.

In the recent investigation, seven agricultural residues such as pomegranate peel, sappota peel, pineapple peel, orange peel, lemon peel, grape peel and sugarcane baggasse have been used as substrates. maximum amount of invertase production of $0.36 \pm 0.011 \mathrm{IU} / \mathrm{ml}$ was recorded in orange peel and minimum invertase production of $0.13 \pm 0.011$ $\mathrm{IU} / \mathrm{ml}$ was recorded in sugarcane baggasse by Saccharomyces cerevisiae MK. Agro-industrial substrates are considered best for enzyme production. However, some newly developed agro-industrial wastes used for enzyme production are banana wastes, rice straw, corncob residue, rice husk, wheat straw, banana fruit stalk and coconut coir pith[35,41]. Several agricultural residue such as wheat bran, oat meal, rice straw, sugarcane baggasse, corncob crushed, cassava flour, soy bean bran, wheat bran + oat meal, wheat bran + cassava flour, wheat bran + soybean bran etc. have been used as substrate. Whereas, some investigated that Wheat bran + oat meal was the best agro-industrial residues as carbon source for Aspergillus caespitosus. Recently, agro-industrial wastes have been used as carbon, hydrogen and oxygen sources to produce ethanol, proteins and microbial enzymes stated by $[36,37]$.

In the present study effect of different concentration of agricultural residues on invertase production was studied in Saccharomyces cerevisiae MK. maximum invertase production of $0.48 \pm 0.011 \mathrm{IU} / \mathrm{ml}$ by was registered in $4 \%$ sucrose concentration and minimum amount of invertase production of $0.15 \pm 0.005 \mathrm{IU} / \mathrm{ml}$ was registered in $8 \%$ sucrose concentration by Saccharomyces cerevisiae MK.

\section{Conclusion}

The data gathered in this study provides evidence for the invertase producing ability of the toddy palm isolate. The production of invertase and sucrose substrate interactions of yeast strain in the toddy palm was the evident through this study. More over this study gives us a hint as well as the microbial wealth of invertase producing yeast which can be harnessed for biotechnological processes.

\section{Acknowledgements}

The facilities provided in the Department of Microbiology of Ayya Nadar Janaki Ammal College, Sivakasi to carry out this study are gratefully acknowledged. 


\section{REFERENCES}

[1] S. Talekar, V. Ghodake, A. Kate, N. Samant, C. Kumar, S. Gadagkar. Australian Preparation and Characterization of Cross-linked Enzyme Aggregates of Saccharomyces Cerevisiae Invertase, Journal of Basic and Applied Sciences, Vol.4 (10): 4760-4765, 2010.

[2] R. D. Klein, M. R. Deibel Jr, J. L. Sarcich, H. A. Zurcher-Neely, I. M. Reardon R. L. Heinrikson. Purification and characterization of invertase from a novel industrial yeast, Schwanniomyces occidentalis, Prep. Biochem, 19: 293-319, 1989

[3] M. C. Silveira, E. M. Oliveira, E, Carvajal, E, P, Bon. Nitrogen regulation of Saccharomyces cerevisiae invertase. Role of the URE2 gene, Appl. Biochem. Biotechnol, 84-86: 247-254, 2000.

[4] I. U1-Haq, S. Ali. Invertase Production from a Hyper producing Saccharomyces Cerevisiae Strain Isolated From Dates, Pak. J. Bot, Vol.37 (3): 749-759.

[5] A. Sturm. Invertases. Primary structure, functions, and roles in plant development and sucrose partitioning, Plant Physiol, 121, 1-7. 1999.

[6] C. Herwig, C. Doerries, I. Marison, U. V. Stockar. Quantitative analysis of the regulation scheme of invertase expression in Saccharomyces cerevisiae, Biotechnol. Bioeng, $76,247-258,2001$

[7] T. Sivakumar, T. Shankar, P. Vijayabaskar, V. Ramasubramanian. Optimization for Keratinase Enzyme Production Using Bacillus thuringiensis TS2, Academic Journal of Plant Sciences, Vol.5 (3): 102-109. 2012a.

[8] S. Mahendran, S. Sankaralingam, T. Shankar, P. Vijayabaskar. Alkalophilic protease enzyme production from estuarine Bacillus aquimaris, World Journal of Fish and Marine Science., 2(5): 436-443, 2010.

[9] K. Shafiq, S. Ali, I. Ul-Haq. Temperature optima for invertase secretion by yeast in synthetic medium, Pak. J. Life Soc, Vol.2 (1): 21-23. 2004

[10] M. L. Cazetta, J. Contiero. Influence of nitrogen source and sucrose concentration on inulinase production by Kluyveromyces marxianus in fed-batch fermentation, African Journal of Biotechnology, Vol.10 (56): 12012-12017, 2011.

[11] T. Shankar, L. Isaiarasu. Cellulase production by Bacillus pumilus EWBCM1 under varying cultural condition, Middle-East Journal of Scientific Research, 8(1): 40-45, 2011.

[12] M. Baig, K. Shafiq, S. Mirza, S. Ali, I. Ul-Haq. Effect of urea as an inducer of $\beta$-fructofuranosidase in Saccharomyces fermentation, Pakistan Journal of Nutrition, 2(2): 106-108, 2003.

[13] S. Sankaralingam, T. Shankar, K. Sendeshkannan, R. Ramasubburayan, S. Prakash. Production of protease from Pseudomonas sp. by immobilization approach on different matrices, European Journal of Applied Sciences, Vol. 4(4): 146-156, 2012.

[14] T. Sivakumar, T. Shankar, P. Vijayabaskar, V. Ramasubramanian. Optimization of keratinase enzyme production using Bacillus thuringiensis TS2, Acadamic Journal of Plant Sciences, Vol. 5(3): 102-109, 2011.

[15] P. Suresh, Kamble, C. B. Jyotsna. Effect of nitrogen sources on the production of invertase by yeast Saccharomyces cerevisiae 3090, International Journal of Applied Biology and Pharmaceutical Technology, Vol. 2: 539-550, 2012.

[16] R. Satheeskumar D. Prabhu, T. Shankar, S. Sankaralingam, K. T. K. Anandapandian. Optimization of alkalophilic protease production by Pseudomonas aeruginosa isolated from the gut of Penaus mondon, World Journal of Fish and Marine Sciences, Vol. 3 (5): 371-375, 2011.

[17] T. Sivakumar, S. Sivasankaranarayani, T. Shankar, P. Vijayabaskar. Statistical optimization of exopolysaccharide production by Frateuria aurentia, International Journal of Biological and Pharmaceutical Research, Vol. 3(3): 457-462, 2012b.

[18] T. Sivakumar, S. Sivasankaranarayani, T. Shankar, P, Vijayabaskar. Optimization of cultural condition for exopolysaccharide production by Frateuria aurentia, International Journal of Applied Biology and Pharmaceutical Technology, Vol. 3(3): 133-144, 2012c.

[19] S. Sankaralingam. Investigation on optimization and characterization of protease produced by Bacillus flexus and Pseudomonas sp. Ph.D. Thesis, Manonmanium Sundaranar University, Tirunelveli, India. 2011.

[20] C. Uma, D, Gomathi, G. Ravikumar, M. Kalaiselvi, M. Palaniswamy. Production and properties of invertase from a Cladosporium cladosporioides in $\mathrm{SmF}$ using pomegranate peel waste as substrate, Asian Pacific Journal of Tropical Biomedicine S605-S611. 2012.

[21] T. Shankar. Characterization and optimization of bacterial cellulase from earthworm gut flora. Ph.D. Thesis, Madurai Kamaraj University, Madurai, India. (2012).

[22] D. Porro, E. Martegani, A. Tura B. M. Ranzi. Development of a $\mathrm{pH}$ controlled fed-batch system for budding yeast, Res. Microbiol, 142(5): 535-539, 1991.

[23] P. Costaglioli, E. Meilhoc, I. Janatova, R. Klein, J. Masson. Secretion of invertase from Schwanniomyces occidentalis, Biotechnol. Lett, 19: 623-627, 1997.

[24] P. Vrabel, M. Polakovic, V. Stefuca, V. Bales. Analysis of mechanisms and kinetics of thermal inactivation of enzymes: evaluation of multi temperature data applied to inactivation of yeast invertase, Enzyme Microb. Technol, 20(5):348-354, 1997.

[25] M. M. Rashad, M. U. Nooman. Production, purification and characterization of extracellular invertase from Saccharomyses cerevisiae NRRL Y-12632 by solid-state fermentation of red carrot residue, Australian Journal of Basic and Applied Sciences, 3(3): 1910-1919, 2009.

[26] R. G. Dworschack, L. J. Wickerham. Extracellular invertase by sucrose-fermenting yeasts. U.S Patent 2953500. 1960.

[27] C. Uma, D. Gomathi, C. Muthulakhmi, V. K. Gopalakrishnan. Production, purification and characterization of invertase by Aspergillus flavus using fruit peel waste as substrate, Adv. Biol. Res, 1: 31-36, 2010.

[28] C. Laluce. Current aspects of fuel ethanol production in 
Brazil, Critical Reviews in Biotechnology, 11(2): 149-161, 1991.

[29] J. Cairns, B. R. Niederlehner, E. P. Smith. Fundamentals in aquatic toxicology: Effects, environmental fate, and risk assessment, 2nd edition. pp, 589-607, 1995.

[30] M. Vitolo, M. A. Duranti, M. B. Pellegrim. Effect of pH, aeration and sucrose feeding on the invertase activity of intact S. cerevisiae cells grown in sugarcane blackstrap molasses, J. Ind. Microbiol, 15(2): 75-79, 1995.

[31] D. K. Myers, D. T. Lawlor, P. V. Attfield. Influence of invertase activity and glycerol synthesis and retention on fermentation of media with a high sugar concentration by Saccharomyces cerevisiae, Applied and Environmental Microbiology., 63(1): 145-150, 1997.

[32] B. W. Kim, H. J. Kwon, H. Y. Park, S. W. Nam, J. P. Park, J. W. Yan. Production of novel transfructosylating enzyme from Bacillus macerans EG-6, Bioprocess Engineering., 23: 11-16, 2000.

[33] C. Uma, D. Gomathi, C. Muthulakhmi, V. K. Gopalakrishnan. Production, purification and characterization of invertase by Aspergillus flavus using fruit peel waste as substrate, Adv. Biol. Res, 1: 31-36, 2010.

[34] I. Ul-Haq, K. Shafiq, S. Ali. Substrate-induced repression of invertase synthesis by Saccharomyces cerevisiae in submerged culture, Pak. J. Bot, Vol. 35(4): 527-531, 2003.
[35] I. P. Bokosa, A. Krastanov, Z. I. Roshkova. Invertase biosynthesis by Saccharomyces cerevisiae. Nauchni. Tr. J., 39(1): 269-279, 1992.

[36] M. Elorza, R. Villanuena, R. Sentandreu. The mechanism of catabolite inhibition of $\beta$-D-fructofuranosidase fructohydrolase by glucose in Saccharomyces cerevisiae, Biochimie. Biophy. Acta, 475: 103-112, 1977.

[37] H. S. Paine, C. F. Walton, M. S. Badollet. Industrial applications of invertase, Indst. Eng. Chem, 17(5): 445-450, 1925.

[38] M. Carlson. Glucose repression in yeast, Curr. Opin. Microbial, 2: 202-207, 1999.

[39] A. Pandey, C. Soccol, J. Rodriguez-Leon, P. Nigam. In: Solid-state fermentation in biotechnology-fundamentals and applications, Asiatech Publ. Inc., New Delhi, pp. 50-225, 2001.

[40] A. C. P. Alegre, M. D. L. T. D. M. Polizeli, H. F. T. J. A. Jorge, L. H. S. Guimaraes. Production of thermostable invertases by Aspergillus caespitosus under submerged or solid state fermentation using agro industrial residues as carbon source, Brazilian Journal of Microbiology, Vol. 40: 612-622, 2009.

[41] L. A. Oliveira, A. L. F. Porto, E. B. Tambourgi. Production of xylanase and protease by Penicilium janthellum CRC 87 M-115 from different agricultural waste, Bioresour. Technol, 97: 862-867, 2006. 